\title{
Physical Properties, Nutritional Composition and Sensory Evaluation of Cookies Prepared from Rice, Unripe Banana and Sprouted Soybean Flour Blends
}

\author{
Ufot Evanson Inyang ", Comfort Friday Effiong, Anne Peter Edima-Nyah \\ Department of Food Science and Technology, Faculty of Agriculture, University of Uyo, Uyo, Nigeria
}

Email address:

inyang.ufot@yahoo.com (U. E. Inyang)

${ }^{*}$ Corresponding author

\section{To cite this article:}

Ufot Evanson Inyang, Comfort Friday Effiong, Anne Peter Edima-Nyah. Physical Properties, Nutritional Composition and Sensory Evaluation of Cookies Prepared from Rice, Unripe Banana and Sprouted Soybean Flour Blends. International Journal of Food Science and Biotechnology. Vol. 3, No. 2, 2018, pp. 70-76. doi: 10.11648/j.ijfsb.20180302.15

Received: May 9, 2018; Accepted: May 22, 2018; Published: June 28, 2018

\begin{abstract}
The present study was aimed at assessing the physical properties, nutrient composition, and sensory characteristics of cookies produced from blends of rice, unripe banana and sprouted soybean flours. The blending ratios (rice: unripe banana: soybean flours) used for the study were 33.33:33.33:33.33 $\left(\mathrm{T}_{1}\right)$, 50:30:20 $\left(\mathrm{T}_{2}\right)$, 30:50:20 $\left(\mathrm{T}_{3}\right)$, 60:15:25 $\left(\mathrm{T}_{4}\right)$, and 70:20:10 $\left(\mathrm{T}_{5}\right)$. The result showed that the physical characteristics, proximate composition, mineral content and sensory attributes of the cookies varied with the proportion of individual flours in the composite mixture. The cookies weight, diameter, thickness and spread ratio ranged from $16.62 \mathrm{~g}, 3.91 \mathrm{~cm}, 0.73 \mathrm{~cm}$ and 4.44 to $20.14 \mathrm{~g}, 4.20 \mathrm{~cm}, 0.91 \mathrm{~cm}$ and 5.36 respectively. The spread ratio increased with increased in soybean flour addition. The crude protein and fat contents increased while carbohydrate content decreased with increased in soybean flour incorporation ranging from $10.71 \%, 15.98 \%$ and $69.26 \%$ to $14.35 \%, 19.04 \%$ and $61.92 \%$ respectively. The $\mathrm{Ca}, \mathrm{K}, \mathrm{Na}, \mathrm{Mg}, \mathrm{Fe}$ and $\mathrm{Zn}$ contents in the cookies ranged from $46.28 \mathrm{mg} / 100 \mathrm{~g}$, $228.20 \mathrm{mg} / 100 \mathrm{~g}, \quad 7.69 \mathrm{mg} / 100 \mathrm{~g}, 27.15 \mathrm{mg} / 100 \mathrm{~g}, 2.75 \mathrm{mg} / 100 \mathrm{~g}$ and $1.99 \mathrm{mg} / 100 \mathrm{~g}$ to $62.30 \mathrm{mg} / 100 \mathrm{~g}, 245.08 \mathrm{mg} / 100 \mathrm{~g}$, $10.64 \mathrm{mg} / 100 \mathrm{~g}, 35.20 \mathrm{mg} / 100 \mathrm{~g}, 3.72 \mathrm{mg} / 100 \mathrm{~g}$ and $2.95 \mathrm{mg} / 100 \mathrm{~g}$ respectively. Cookies produced from $50 \%$ rice, $30 \%$ unripe banana and $20 \%$ sprouted soybean flour blend as well as 30\% rice, 50\% unripe banana and $20 \%$ sprouted soybean flour blend were the most preferred cookies by the panelists in terms of taste, texture and overall acceptability. It is evident from the study that acceptable cookies of high nutritive value could be produced from blends of rice, unripe banana and sprouted soybean flours. This will increase the utilization of these locally grown crops and reduce wheat importation into the country.
\end{abstract}

Keywords: Rice Flour, Unripe Banana Flour, Sprouted Soybean Flour, Cookies, Physicochemical Properties, Sensory Characteristics

\section{Introduction}

Cookies are ready-to-eat popular snack foods that are widely consumed by people of all ages due to their affordability, convenience, long shell life and nutritive value [1]. Traditionally, cookies are made from wheat flour but could also be made from other flours. In Nigeria, the local production of wheat is far below domestic consumption because of unfavourable climatic conditions. Consequently, wheat is imported into the country to augment the local production. This wheat importation places a considerable burden on the foreign exchange reserve of Nigeria's economy. The use of composite flour from locally grown crops in cookies production will be of economic advantage as this will reduce the reliance on wheat importation and thus enhance the industrial utilization of locally grown crops. Also, since cookies are widely accepted and consumed by people of all ages, they therefore offer a valuable supplementation vehicle for nutritional improvement [2].

Rice (Oryza sativa) is one of the staple crops cultivated and consumed mainly as a whole grain in Nigeria. Besides being a food free of enzyme inhibitors that impair the absorption of nutrients, rice has a bland taste, white colour and hypoallergenic properties [3]. According to Yimaki et al. [4], rice flour can be used as a wheat flour replacement since it lacks gluten, contains low level of sodium and a high 
amount of easily digestible carbohydrates, making it desirable in celiac diets. Rice is a rich source of carbohydrate with starch as its main component [5]. It contains a moderate amount of protein and fat, and is a source of vitamin - B complex including thiamine, riboflavin and niacin [6], and minerals such as calcium, magnesium and phosphorus as well as some traces of iron, copper, zinc and manganese [7]. Its protein is highly digestible with excellent biological value and protein efficiency ratio [8]. Due to its nutritional quality and higher digestibility, rice is considered as the qun among cereals [9].

Bananas (Musa sapientum) are grown worldwide in tropical countries and are fourth most important food crop after rice, wheat and maize [10]. It is a climacteric fruit with short shelf-life after harvest. Banana fruits are usually traded in the fresh form and the populations in general have the habit of consuming only the ripe fruits. High postharvest losses in quantity and quality are usually encountered due to poor handling, bulk transportation, rapid ripening and lack of processing technologies. Processing of fresh banana fruits into flour is an excellent alternative to minimize postharvest losses and add value to the product [11]. The flour could be incorporated into various innovative products such as high fibre bread [12], slowly digestible cookies [13] and edible films [14]. Nutritionally, banana flour is a good source of carbohydrate with high level of resistant starch that may help control blood sugar, manage weight and lower blood cholesterol [11]. It also contains minerals and vitamins. Consumption of green bananas has been reported to have beneficial effects on diseases such as colorectal cancer, diarrhea, insulin response, dyslipidemia, cardiovascular disease and celiac disease $[15,16]$.

Most baked products are made from carbohydrate based flours like wheat, potato, rice and banana flours with low protein content. Incorporation of soybean flour in rice and banana flour blends will help to improve the nutritional value of the flour and the flour could be used to alleviate the problem of protein-energy malnutrition that is still prevalent in developing countries including Nigeria. Soybean (Glycine max) is an excellent and inexpensive source of high quality protein comparable to meat, poultry and eggs [17]. However, the high level of anti-nutrients in raw soybean can cause adverse health effect to consumers. Sprouting of the beans prior to milling into flour is a very effective technology for reducing the anti-nutrients and improving the nutritive value of soy flour. Germination/sprouting have been reported to induce increase in the amount of free limiting amino acids and available vitamins with modified functional properties of seed components [18]. The utilization of non-wheat composite flours in the production of baked products can serve as alternative means of diversifying these flours, add value to the products, increase protein intake of the consumers of the products and reduce wheat importation. The present study was aimed at assessing the physical properties, nutritional composition and sensory attributes of cookies made from rice, unripe banana and sprouted soybean flour blends.

\section{Materials and Methods}

\subsection{Materials Procurement}

Mature green but unripe banana ("Mboro Ukom" cultivar), soybeans and ingredients used for cookies production (sugar, butter, salt, milk powder, sodium bicarbonate, egg and vanilla essence) were purchased from Akpan Andem Market in Uyo, Akwa Ibom State while local rice was purchased from rice mill in Ini Local Government Area of Akwa Ibom State, Nigeria

\subsection{Material Preparation}

\subsubsection{Preparation of Rice Flour}

Rice flour was produced following the method described by Okpala and Egwu [19]. The rice grains were cleaned by manually removing extraneous materials like stone, chaff and stalks. The grains were washed with potable water, sun dried, milled using hammer mill and sieved through a mesh of 425 micrometer aperture screen. The flour was packaged in airtight plastic container, labeled and stored at ambient temperature $\left(27 \pm 2^{\circ} \mathrm{C}\right)$ for subsequent use.

\subsubsection{Preparation of Unripe Banana Flour}

Unripe banana flour was produced following the method described by Adeyemi et al. [20]. The banana fruits were removed from bunches, washed in potable water; steam blanched at $100^{\circ} \mathrm{C}$ for 10 minutes, cooled and peeled using a stainless knife. The peeled bananas were sliced ( $1 \mathrm{~cm}$ thick) and placed in water. The water was drained off and the sliced pieces dried in a conventional air oven (model PP. 22 US, Genlab, England) at $60^{\circ} \mathrm{C}$ to constant weight. The dried pieces were milled using hammer mill, sieved through a mesh of 425 micrometer pore size screen, packaged in air tight plastic container, labeled and stored at ambient temperature $\left(27 \pm 2^{\circ} \mathrm{C}\right)$ for subsequent use.

\subsubsection{Preparation of Sprouted Soybean Flour}

Sprouted soybean flour was produced using the method described by Jideani and Onwubali [18] with slight modifications. The seeds were cleaned by sorting to remove infected and immature seeds as well as other foreign materials. Sorted seeds were washed, soaked in water (1:4 $\mathrm{w} / \mathrm{v})$ at ambient temperature $\left(27 \pm 2^{\circ} \mathrm{C}\right)$ for 18 hours, drained, washed and spread on perforated trays lined with previously sterilized wet cotton cloth and covered with wet muslin cloth. The trays containing the seeds were kept in a cupboard away from light and the seeds kept wet by sprinkling with water every 6 hours till the end of the sprouting period ( $48 \mathrm{~h}$ ). The sprouted seeds were washed and dried in a conventional air oven (model PP. $22 \mathrm{US}$, Genlab, England) at $60^{\circ} \mathrm{C}$ for $24 \mathrm{~h}$. The rootlets and hull were removed and discarded while the cotyledons were milled into flour using hammer mill, sieved through a mesh of 425 micrometer aperture screen, packaged in air tight container, labeled and stored at ambient temperature $\left(27 \pm 2^{\circ} \mathrm{C}\right)$ for subsequent use. 


\subsubsection{Formulation of Composite Flours}

Five composite flours with different proportions of rice, unripe banana and sprouted soybean flours were formulated and designated as $\mathrm{T}_{1}, \mathrm{~T}_{2}, \mathrm{~T}_{3}, \mathrm{~T}_{4}$, and $\mathrm{T}_{5}$, The blending ratios are shown on Table 1.

Table 1. Formulation of composite flours (\%).

\begin{tabular}{llllll}
\hline Samples & $\mathbf{T}_{\mathbf{1}}$ & $\mathbf{T}_{\mathbf{2}}$ & $\mathbf{T}_{\mathbf{3}}$ & $\mathbf{T}_{\mathbf{4}}$ & $\mathbf{T}_{\mathbf{5}}$ \\
\hline Rice flour & 33.33 & 50 & 30 & 60 & 70 \\
Banana flour & 33.33 & 30 & 50 & 15 & 20 \\
Soybean flour & 33.33 & 20 & 20 & 25 & 10 \\
\hline
\end{tabular}

\subsubsection{Ingredients Formulation and Cookies Production}

Ingredients formulation (Table 2) and creamy method of cookies production as reported by Okpala et al. [21] were used for cookies production with slight modifications. Butter and granulated sugar were creamed together for $5 \mathrm{~min}$. Eggs and powdered milk was added while mixing and continued to cream until light and fluffy. Flour, sodium bicarbonate, salt and vanilla flavour were thoroughly mixed and added to the cream mixture and mixed in a bowel mixer to form dough. The dough was kneaded to a uniform thickness, cut to a uniform diameter, left in a freezer for 30 minutes to rest, baked in an oven at $180^{\circ} \mathrm{C}$ for 20 minutes, cooled at ambient temperature $\left(27 \pm 2^{\circ} \mathrm{C}\right)$, packaged in high density polyethylene, labeled and stored at ambient temperature for various determinations.

Table 2. Ingredients formulation for cookies production.

\begin{tabular}{llllll}
\hline Ingredients & $\mathbf{T}_{\mathbf{1}}$ & $\mathbf{T}_{\mathbf{2}}$ & $\mathbf{T}_{\mathbf{3}}$ & $\mathbf{T}_{\mathbf{4}}$ & $\mathbf{T}_{\mathbf{5}}$ \\
\hline Flour (g) & 100 & 100 & 100 & 100 & 100 \\
Butter (g) & 40 & 40 & 40 & 40 & 40 \\
Sugar (g) & 25 & 25 & 25 & 25 & 25 \\
Egg (g) & 31 & 31 & 31 & 31 & 31 \\
Powdered milk (g) & 7.8 & 7.8 & 7.8 & 7.8 & 7.8 \\
Sodium bicarbonate (g) & 1 & 1 & 1 & 1 & 1 \\
Salt (g) & 1 & 1 & 1 & 1 & 1 \\
Vanilla essence (ml) & 5 & 5 & 5 & 5 & 5 \\
\hline
\end{tabular}

\subsection{Methods of Analysis}

\subsubsection{Determination of Physical Properties of Cookies}

Weight of the cookies was measured using a digital weighing balance and mean values of five individual cookies recorded. The cookies diameter (width) was determined by placing six cookies horizontally (edge to edge) in a row and the diameter was measured with a digital vernier caliper with $0.01 \mathrm{~mm}$ accuracy [22]. The mean value was recorded as the diameter of the cookies. Thickness of cookies was determined by stacking six cookies, one on top of another and thickness was taken using digital vernire caliper with $0.01 \mathrm{~mm}$ accuracy [22]. The mean value was recorded as the thickness of the cookies. The spread ratio was calculated as the average diameter/thickness [23].

\subsubsection{Determination of Nutrient Composition of Cookies}

Moisture, crude protein, crude fat, ash and crude fibre were determined using the methods described in AOAC [24]. Carbohydrate content was calculated by difference [25]. Energy value was calculated using Atwater factor formula as described by Osborne and Voogt [26]. Mineral content (Ca, $\mathrm{K}, \mathrm{Na}, \mathrm{Mg}, \mathrm{Fe}$ and $\mathrm{Zn}$ ) were determined using atomic absorption spectrophotometer (UNICAM model 939, UK) as described in AOAC [24].

\subsubsection{Sensory Evaluation}

The sensory evaluation of produced cookies was performed by 20 semi-trained panels of judges drawn from the Department of Food Science and Technology, University of Uyo, Uyo, Nigeria. All panelists were regular consumers of cookies and were familiar with quality attributes of cookies. The evaluation was conducted using the nine-point hedonic scale ranging from 1(disliked extremely) to 9(liked extremely) as described by Ihekoronye and Ngoddy [27]. The samples were coded with three digit random numbers and presented in identical containers. Questionnaire for entering scores and potable water for mouth rinsing between tasting were made available to the panelists. Each of the samples was rated for appearance, taste, texture, crispiness and overall acceptability.

\subsection{Statistical Analysis}

Data obtained were subjected to a one-way Analysis of Variance (ANOVA) using the software statistical package for social sciences (SPSS) version 18 (SPSS, Inc, Chicago, USA) to determine significant difference at $\mathrm{P}<0.05$. Means were separated using Duncan's Multiple Range Test (DMRT).

\section{Results and Discussion}

\subsection{Physical Characteristics of Cookies}

The mean values of physical characteristics of cookies prepared from composite flour blends of rice, unripe banana and sprouted soybean are presented in Table 3.

Table 3. Physical properties of cookies produced from rice, unripe banana and sprouted soybean flour blends.

\begin{tabular}{lllll}
\hline Parameters & $\mathbf{T}_{\mathbf{1}}$ & $\mathbf{T}_{\mathbf{2}}$ & $\mathbf{T}_{\mathbf{3}}$ & $\mathbf{T}_{\mathbf{4}}$ \\
\hline Weight $(\mathrm{g})$ & $16.62^{\mathrm{c}} \pm 0.15$ & $19.07^{\mathrm{b}} \pm 0.09$ & $18.80^{\mathrm{b}} \pm 0.02$ & $16.92^{\mathrm{c}} \pm 0.10$ \\
Diameter $(\mathrm{cm})$ & $3.91^{\mathrm{b}} \pm 0.04$ & $4.20^{\mathrm{a}} \pm 0.06$ & $4.11^{\mathrm{a}} \pm 0.05$ & $20.14^{\mathrm{a}} \pm 0.03$ \\
Thickness $(\mathrm{cm})$ & $0.73^{\mathrm{c}} \pm 0.11$ & $0.90^{\mathrm{a}} \pm 0.03$ & $0.87^{\mathrm{a}} \pm 0.02$ & $4.02^{\mathrm{a}} \pm 0.14$ \\
Spread ratio & $5.36^{\mathrm{a}} \pm 0.02$ & $4.67^{\mathrm{b}} \pm 0.10$ & $4.72^{\mathrm{b}} \pm 0.04$ & $0.82^{\mathrm{b}} \pm 0.08$ \\
\hline
\end{tabular}

Values are means \pm SD (standard deviation) of triplicate determinations. Means on the same row with different superscripts are significantly different at $\mathrm{P}<0.05 . \mathrm{T}_{1}=33.33 \%$ rice flour, $33.33 \%$ banana flour and $33.33 \%$ soybean flour; $\mathrm{T}_{2}=50 \%$ rice flour, $30 \%$ banana flour and $20 \%$ soybean flour; $\mathrm{T}_{3}=30 \%$ rice flour, $50 \%$ banana flour and $20 \%$ soybean flour; $\mathrm{T}_{4}=60 \%$ rice flour, $15 \%$ banana flour and $25 \%$ soybean flour; $\mathrm{T}_{5}=70 \%$ rice flour, $20 \%$ banana flour and $10 \%$ soybean flour. 
The result showed that the physical characteristics of the prepared cookies varied with the variation in the proportion of individual flours in the different blends. Similar observations have been reported by other authors [21, 22, 28-29]. The cookies weight ranged from $16.62 \mathrm{~g}$ to $20.14 \mathrm{~g}$ with cookies that contained the highest percentage of soybean flour $(33.33 \%)\left(T_{1}\right)$ having the least weight while cookies with the least percentage of soybean flour $(10 \%)\left(\mathrm{T}_{5}\right)$ had the highest weight. This observation is in agreement with the reports by other authors [30-32]. The recorded lower weight of cookies with increase in soybean flour addition could be due to higher fat content of the soybean flour relative to other flours as fat is lighter in weight than water [30]. The diameter and thickness of the produced cookies ranged from $3.91 \mathrm{~cm}$ and $0.73 \mathrm{~cm}$ to $4.20 \mathrm{~cm}$ and $0.91 \mathrm{~cm}$ respectively. These variations in cookies diameter and thickness are reflected in the spread ratio which was calculated by dividing diameter by thickness of the cookies. Spread ratio of cookies has long been used as an important characteristic for determining the quality of flour for cookies production [33]. Cookies with higher values of spread ratio are considered to be more desirable than those with lower values [28]. In the present study, cookies prepared from the composite flour with $33.33 \%$ soybean flour addition $\left(\mathrm{T}_{1}\right)$ had the highest spread ratio (5.36) while the least value (4.44) was recorded for the cookies from the blend with the least (10\%) soybean flour addition $\left(\mathrm{T}_{5}\right)$. This observation is in agreement with the reports by other authors [28-32]. Cookies prepared from the blend that contained 33.33\% soybean flour might have exhibited the lowest viscosity which resulted in the highest spread ratio. According to Miller et al. [34], dough's with lower viscosity cause cookies to spread at faster rate and vice versa. Singh et al. [35] had earlier documented that the spread ratio of cookies increased with increase in the content of non-wheat protein. Increase in spread ratio could also be attributed to increase in the hydrophilic sites in the dough mixture leading to increase in water absorption and swelling index [29].

\subsection{Proximate Composition of Produced Cookies}

The proximate composition of cookies produced from composite flours of rice, unripe banana and sprouted soybean is presented in Table 4.

Table 4. Proximate composition of cookies produced from rice, unripe banana and sprouted soybean flour blends (dry matter basis).

\begin{tabular}{lllll}
\hline Parameters & $\mathbf{T}_{\mathbf{1}}$ & $\mathbf{T}_{\mathbf{2}}$ & $\mathbf{T}_{\mathbf{3}}$ & $\mathbf{T}_{\mathbf{4}}$ \\
\hline Crude protein (\%) & $14.35^{\mathrm{c}} \pm 0.15$ & $12.95^{\mathrm{b}} \pm 0.10$ & $12.25^{\mathrm{b}} \pm 0.14$ & $13.50^{\mathrm{a}} \pm 0.02$ \\
Crude fat (\%) & $19.04^{\mathrm{b}} \pm 0.04$ & $17.20^{\mathrm{c}} \pm 0.08$ & $17.13^{\mathrm{c}} \pm 0.02$ & $18.51^{\mathrm{b}} \pm 0.11$ \\
Ash (\%) & $1.95^{\mathrm{c}} \pm 0.11$ & $1.71^{\mathrm{a}} \pm 0.05$ & $1.73^{\mathrm{a}} \pm 0.00$ & $1.64^{\mathrm{a}} \pm 0.02$ \\
Crude fibre (\%) & $2.74^{\mathrm{a}} \pm 0.02$ & $2.70^{\mathrm{a}} \pm 0.21$ & $2.95^{\mathrm{a}} \pm 0.15$ & $15.98^{\mathrm{a}} \pm 0.10$ \\
Carbohydrate (\%) & $61.92^{\mathrm{c}} \pm 0.11$ & $65.44^{\mathrm{b}} \pm 0.05$ & $65.94^{\mathrm{b}} \pm 0.02$ & $2.53^{\mathrm{a}} \pm 0.06$ \\
Caloric value (kcal/100g) & $476.44^{\mathrm{a}} \pm 0.02$ & $468.36^{\mathrm{b}} \pm 0.01$ & $466.93^{\mathrm{b}} \pm 0.05$ & $63.82^{\mathrm{c}} \pm 0.04$ \\
\hline
\end{tabular}

Values are means $\pm \mathrm{SD}$ (standard deviation) of triplicate determinations. Means on the same row with different superscripts are significantly different at $\mathrm{P}<0.05 . \mathrm{T}_{1}=33.33 \%$ rice flour, $33.33 \%$ banana flour and $33.33 \%$ soybean flour; $\mathrm{T}_{2}=50 \%$ rice flour, $30 \%$ banana flour and $20 \%$ soybean flour; $\mathrm{T}_{3}=30 \%$ rice flour, $50 \%$ banana flour and $20 \%$ soybean flour; $\mathrm{T}_{4}=60 \%$ rice flour, $15 \%$ banana flour and $25 \%$ soybean flour; $\mathrm{T}_{5}=70 \%$ rice flour, $20 \%$ banana flour and $10 \%$ soybean flour.

The result showed that the proximate composition of the cookies varied with the proportion of the three flours in the formulated blends. The variations could be attributed to differences in the chemical constituents of individual flours used in composite flour formulation. The crude protein, fat and carbohydrate contents in the cookies ranged from $10.71 \%, 15.98 \%$ and $61.92 \%$ to $14.35 \%, 19.04 \%$ and $69.26 \%$ respectively. Significant differences $(\mathrm{P}<0.05)$ were observed in the crude protein, fat and carbohydrate values and were related to the increment of the soybean flour content in the recipe. The crude protein and fat contents of the cookies increased while carbohydrate decreased with the increase in soybean flour incorporation. This observation could be due to higher contents of protein and fat and lower content of carbohydrate in soybean flour relative to rice and unripe banana flours. These results are in agreement with the reports by other authors [30, 36, 37]. The result indicates that cookies of improved protein content could be produced from blends of rice, unripe banana and sprouted soybean flours.

The ash content of a food sample is an index of the mineral elements of such food. The ash content of the cookies varied insignificantly $(\mathrm{P}>0.05)$ from $1.50 \%$ to $1.95 \%$ with cookies from the blend of $70 \%$ rice, $20 \%$ unripe banana and $10 \%$ soybean flours $\left(\mathrm{T}_{5}\right)$ having the least value while the highest value was for the cookies prepared from the blend that composed of equal levels $(33.33 \%)$ of the three flours $\left(\mathrm{T}_{1}\right)$. Cookies from composite flour with higher percentage of banana flour than rice flour exhibited slightly higher ash content than the blends with higher percentage rice flour. This indicates that banana flour would contribute more mineral elements to the products than rich flour. The crude fibre content of the cookies varied insignificantly $(\mathrm{P}>0.05)$ from $2.53 \%$ to $2.95 \%$. Cookies from $50 \%$ banana flour, $30 \%$ rice and $20 \%$ soybean flours $\left(\mathrm{T}_{3}\right)$ recorded the highest value while the counterpart from $60 \%$ rice, $15 \%$ banana and $25 \%$ soybean flours recorded the least value $\left(\mathrm{T}_{4}\right)$. It has been reported that increased dietary fibre consumption could lead to significantly lower risks for obesity, type 2 diabetes, constipation, colonary heart diseases and some cancer [38]. The caloric value was affected by the percentage of soybean flour in the blends used for cookies production. The caloric value of the samples ranged from $463.70 \mathrm{kcal} / 100 \mathrm{~g}$ for cookies from the blend with $10 \%$ soybean flour $\left(\mathrm{T}_{5}\right)$ to $476.44 \mathrm{kcal} / 100 \mathrm{~g}$ for cookies from the blend with $33.33 \%$ 
soybean flour $\left(T_{1}\right)$. This could be due to higher content of fat in soybean flour relative to rice and unripe banana flours. This observation is in agreement with the reports by other authors $[30,36,37]$.

\subsection{Mineral Content in the Cookies}

The mineral content in cookies produced from composite flours of rice, unripe banana and sprouted soybean is presented in Table 5. The result showed that the mineral elements determined in the present study $(\mathrm{K}, \mathrm{Ca}, \mathrm{Na}, \mathrm{Mg}, \mathrm{Fe}$ and $\mathrm{Zn})$ varied significantly $(\mathrm{P}<0.05)$ among the produced cookies. They could be attributed to the variation in mineral composition of the different flours used in the composite flour formulation. Potassium was the most abundant mineral element in all the cookies produced and was followed by calcium. Potassium value was highest $(245.08 \mathrm{mg} / 100 \mathrm{~g})$ in the cookies produced from the blend with equal proportions $(33.33 \%)$ of the three flours used in the composite flour formulation $\left(\mathrm{T}_{1}\right)$ and differed significantly $(\mathrm{P}<0.05)$ from the values for the other cookies. Cookies produced from the blend of $70 \%$ rice, $20 \%$ unripe banana and $10 \%$ soybean flours $\left(\mathrm{T}_{5}\right)$ recorded the least potassium value $(228.20 \mathrm{mg} / 100 \mathrm{~g})$. According to Androgue and Madias [39], potassium intake is required in relatively large amount in the body because it functions as an important electrolyte in the nervous system. Dietary potassium has been shown to exert a powerful, dosedependent inhibitory effect on sodium sensitivity [39]. Studies have shown that increasing the potassium intake of hypertensive rats that were fed high sodium diets lowered blood pressure, reduced incidence of stroke and stroke-related death, and prevented cardiac hypertrophy, mesenteric vascular damage, and renal injury [40].

Table 5. Mineral content of cookies produced from rice, unripe banana and sprouted soybean flour blends (mg/100g).

\begin{tabular}{lllll}
\hline Minerals & $\mathbf{T}_{\mathbf{1}}$ & $\mathbf{T}_{\mathbf{2}}$ & $\mathbf{T}_{\mathbf{3}}$ & $\mathbf{T}_{\mathbf{4}}$ \\
\hline $\mathrm{Ca}$ & $62.30^{\mathrm{a}} \pm 0.09$ & $51.07^{\mathrm{c}} \pm 0.42$ & $58.71^{\mathrm{b}} \pm 0.50$ & $54.14^{\mathrm{c}} \pm 0.11$ \\
$\mathrm{~K}$ & $245.08^{\mathrm{a}} \pm 0.15$ & $231.72^{\mathrm{b}} \pm 0.10$ & $239.41^{\mathrm{b}} \pm 0.21$ & $241.06^{\mathrm{b}} \pm 0.09$ \\
$\mathrm{Na}$ & $10.64^{\mathrm{a}} \pm 0.27$ & $8.01^{\mathrm{b}} \pm 0.34$ & $7.98^{\mathrm{b}} \pm 0.75$ & $228.20^{\mathrm{c}} \pm 0.14$ \\
$\mathrm{Mg}$ & $34.11^{\mathrm{a}} \pm 0.18$ & $31.64^{\mathrm{b}} \pm 0.96$ & $35.20^{\mathrm{a}} \pm 0.15$ & $9.08^{\mathrm{a}} \pm 0.37$ \\
$\mathrm{Fe}$ & $3.72^{\mathrm{a}} \pm 0.55$ & $3.10^{\mathrm{a}} \pm 0.14$ & $3.68^{\mathrm{a}} \pm 0.37$ & $32.00^{\mathrm{b}} \pm 0.18$ \\
$\mathrm{Zn}$ & $2.95^{\mathrm{a}} \pm 0.41$ & $2.55^{\mathrm{a}} \pm 0.32$ & $2.70^{\mathrm{a}} \pm 0.53$ & $3.49^{\mathrm{a}} \pm 0.06$ \\
\hline
\end{tabular}

Values are means $\pm \mathrm{SD}$ (standard deviation) of triplicate determinations. Means on the same row with different superscripts are significantly different at $\mathrm{P}<0.05 . \mathrm{T}_{1}=33.33 \%$ rice flour, $33.33 \%$ banana flour and $33.33 \%$ soybean flour; $\mathrm{T}_{2}=50 \%$ rice flour, $30 \%$ banana flour and $20 \%$ soybean flour; $\mathrm{T}_{3}=30 \%$ rice flour, $50 \%$ banana flour and $20 \%$ soybean flour; $\mathrm{T}_{4}=60 \%$ rice flour, $15 \%$ banana flour and $25 \%$ soybean flour; $\mathrm{T}_{5}=70 \%$ rice flour, $20 \%$ banana flour and $10 \%$ soybean flour.

The calcium values varied significantly $(\mathrm{P}<0.05)$ among the cookies from different flour blends ranging from $46.28 \mathrm{mg} / 100 \mathrm{~g}$ for cookies produced from blend of $70 \%$ rice, $20 \%$ banana and $10 \%$ soybean flours $\left(\mathrm{T}_{5}\right)$ to $62.30 \mathrm{mg} / 100 \mathrm{~g}$ for cookies produced from the blend with equal levels $(33.33 \%)$ of the three flours $\left(T_{1}\right)$. Calcium plays important role in blood clotting, muscle contraction and in certain enzymes in metabolic processes [41]. Magnesium and sodium contents in the cookies ranged from $27.15 \mathrm{mg} / 100 \mathrm{~g}$ and $7.69 \mathrm{mg} / 100 \mathrm{~g}$ to $35.20 \mathrm{mg} / 100 \mathrm{~g}$ and $10.64 \mathrm{mg} / 100 \mathrm{~g}$ respectively. Magnesium in the diet affects the metabolism of calcium, potassium and sodium [42]. It is important for bone health; is needed as a cofactor for numerous reactions in the body and is also essential for nerve and muscle conductivity [42]. High amount of magnesium, calcium and potassium have been reported to reduce blood pressure in humans [43]. Blood pressure and blood volume are under the regulation and control of sodium. The high potassium and low sodium contents of the cookies make them suitable for use by hypertensive individuals.

There were no significant differences $(\mathrm{P}>0.05)$ between the iron and zinc contents in the cookies except for cookies that were produced from the blend of $70 \%$ rice, $20 \%$ banana and $10 \%$ soybean flours $\left(\mathrm{T}_{5}\right)$ which had significantly $(\mathrm{P}<0.05)$ lower values. The iron and zinc contents ranged from $2.75 \mathrm{mg} / 100 \mathrm{~g}$ and $1.99 \mathrm{mg} / 100 \mathrm{~g}$ to $3.72 \mathrm{mg} / 100 \mathrm{~g}$ and $2.95 \mathrm{mg} / 100 \mathrm{~g}$ respectively. Iron and zinc are critical micronutrients for the growth, development, immunity and health of infants, and are known to be limiting nutrients in the diets of infants and young children [44]. Iron is needed for the formation of hemoglobin, the component of blood cell that carries oxygen in the blood stream throughout the body [42]. Adequate iron in the diet is essential to minimize the incidence of iron deficiency anemia, which is considered as the most common nutritional disorder worldwide [45].

\subsection{Sensory Evaluation of Cookies}

Mean scores of sensory attributes of cookies evaluated are presented in Table 6 .

The result showed that the mean scores by the panelists for appearance, taste, texture, crispiness and overall acceptability varied between the cookies produced from composites of rice, unripe banana and sprouted soybean flours. Appearance and taste are important sensory attributes that affect the acceptability of food products. There was no significant $(\mathrm{P}>0.05)$ different in the mean values for appearance of the cookies. The taste for cookies produced from the composites of $50 \%$ rice, $30 \%$ banana and $20 \%$ soybean flours $\left(\mathrm{T}_{2}\right)$ as well as $30 \%$ rice, $50 \%$ banana and $20 \%$ soybean flours $\left(\mathrm{T}_{3}\right)$ were the most preferred by the panelists and the mean scores were significantly $(\mathrm{P}<0.05)$ different from those of other cookies. 
Ufot Evanson Inyang et al.: Physical Properties, Nutritional Composition and Sensory Evaluation of Cookies Prepared from Rice, Unripe Banana and sprouted Soybean Flour Blends

Table 6. Mean sensory values of cookies produced from rice, unripe banana and sprouted soybean flour blends.

\begin{tabular}{|c|c|c|c|c|c|}
\hline Parameters & $\mathbf{T}_{1}$ & $\mathbf{T}_{2}$ & $\mathbf{T}_{3}$ & $\mathbf{T}_{4}$ & $\mathbf{T}_{5}$ \\
\hline Appearance & $7.0800^{\mathrm{a}} \pm 0.15$ & $6.90^{\mathrm{a}} \pm 0.30$ & $7.00^{\mathrm{b}} \pm 0.10$ & $7.10^{\mathrm{a}} \pm 0.19$ & $7.40^{\mathrm{a}} \pm 0.20$ \\
\hline Taste & $6.40^{c} \pm 0.20$ & $7.08^{\mathrm{a}} \pm 0.17$ & $7.15 \pm 0.14$ & $6.65^{\mathrm{b}} \pm 0.26$ & $6.75^{\mathrm{b}} \pm 0.19$ \\
\hline Texture & $6.35^{\mathrm{b}} \pm 0.11$ & $6.78^{\mathrm{a}} \pm 0.14$ & $6.62^{\mathrm{a}} \pm 0.20$ & $6.45^{\mathrm{b}} \pm 0.13$ & $6.50^{\mathrm{b}} \pm 0.31$ \\
\hline Crispiness & $6.25^{\mathrm{a}} \pm 0.09$ & $6.64^{\mathrm{a}} \pm 0.21$ & $6.55^{\mathrm{a}} \pm 0.15$ & $6.31^{\mathrm{a}} \pm 0.26$ & $6.75^{\mathrm{a}} \pm 0.11$ \\
\hline Overall acceptability & $6.60^{c} \pm 0.14$ & $6.98^{\mathrm{a}} \pm 0.19$ & $7.15^{\mathrm{a}} \pm 0.22$ & $6.85^{\mathrm{b}} \pm 0.11$ & $6.99^{\mathrm{b}} \pm 0.14$ \\
\hline
\end{tabular}

Means on the same row with different superscripts are significantly different at $\mathrm{P}<0.05$. $\mathrm{T}_{1}=33.33 \%$ rice flour, $33.33 \%$ banana flour and $33.33 \%$ soybean flour; $\mathrm{T}_{2}=50 \%$ rice flour, $30 \%$ banana flour and $20 \%$ soybean flour; $\mathrm{T}_{3}=30 \%$ rice flour, $50 \%$ banana flour and $20 \%$ soybean flour; $\mathrm{T}_{4}=60 \%$ rice flour, $15 \%$ banana flour and $25 \%$ soybean flour; $\mathrm{T}_{5}=70 \%$ rice flour, $20 \%$ banana flour and $10 \%$ soybean flour.

Cookies produced from the blend with $33.33 \%$ soybean flour addition had the least rating in terms of taste, texture, crispiness and overall acceptability. The mean scores for crispiness of the cookies insignificantly $(\mathrm{P}>0.05)$ decreased with increased in soybean flour addition. The mean scores for overall acceptability of the cookies showed that cookies produced from blends of $50 \%$ rice, $30 \%$ banana and $20 \%$ soybeans flours $\left(\mathrm{T}_{2}\right)$ as well as $30 \%$ rice, $50 \%$ banana and $20 \%$ soybean flours $\left(\mathrm{T}_{3}\right)$ were the most preferred cookies and were significantly $(\mathrm{P}<0.05)$ different from the rest of the cookies.

\section{Conclusion}

The study has shown that it is possible to use composite of rice, unripe banana and sprouted soybean flour blends to produce acceptable cookies of high nutritional value. The use of these locally grown crops to produce non-gluten cookies will go a long way in reducing the Nation's reliance on wheat importation thereby reducing the amount of foreign exchange used in wheat importation. Successful application of the composite flour in cookies production has the potential to increase the farmer's income by value addition and increase the protein intake of the consumers of the product.

\section{References}

[1] P. Akubor. Functional and performances of cowpea/plantain/wheat flour blends in biscuits. Plant Foods Hum. Nutr. 58:1-8, 2003.

[2] M. U. Arshad, F. M. Anjum and T. Zahoor. Nutritional assessment of cookies supplemented with defatted wheat germ. Food Chem. 102:123-128, 2007.

[3] H. Neumann and J. M. Bruemmer. Investigation with the production of gluten-free bread and roll specialties. Getreide Mohl. Brot. 51:50-55, 1997.

[4] G. Yimaki, Z. J. Hawrysh, R. T. Hardin and B. R. Thomson. Application of response surface methodology to the development of rice flour yeast breads: sensory evaluation. J. Food Sci. 53(3):751-759, 1991.

[5] D. K. Verma and P. P. Srivastav. Proximate composition, mineral content and fatty acid analyses of aromatic and nonaromatic Indian rice. Rice Sci. 24(1):21-31, 2017.

[6] L. Fresco. Rice is life. J. Food Comp. Anal. 18(4):249-253, 2005.

[7] A. O. Oko, B. E. Ubi, A. A. Efisue and N. Dambaba.
Comparative analysis of the chemical nutrient composition of selected local and newly introduced rice varieties grown in Ebonyi State of Nigeria. Int. J. Agric. Forest. 2(2):16-23, 2017.

[8] B. O. Juliano. Nutritional value of rice and rice diets. In: Rice in human nutrition. IRR and FAO, Rome, Italy. 1993, pp. 61-84.

[9] F. M. Anjum, I. Pasha, M. A. Bugti and M. S. Batt. Mineral composition of different rice varieties and their milling fractions. Pak. J. Agric. Sci. 44(2):51-58, 2007.

[10] H. Akcoaz. Analysis of energy use for banana production: A case study from Turkey. Afr. J. Agric. Res. 6(25):5618-5624, 2011.

[11] s. Pragati, I. Genitha and K. Ravish. Comparative study of ripe and unripe banana flour during storage. J. Food Proc. Technol. 5:3-8, 2014.

[12] E. Juarez-Garcia, E. Agama-Acevedo, S. G Sayago-Ayerdi, S. L. Rodriguez-Ambriz and L. A. Bello-Perez. Composition, digestibility and application in bread making of banana flour. Plant Foods Hum. Nutr. 61:131-137, 2006.

[13] A. Aparicio-Saguilan, S. G. Sayago-Ayerdi, A. T. J. VargasTorres, T. E. Ascencio-Otero and L. A. Bello-Perez. Slowly digestible cookies prepared from resistant starch-rich lintnerized banana starch. J. Food Comp. Anal. 20:175-181, 2007.

[14] S. Rungsinee and P. Natcharee. Oxygen permeability and mechanical properties of banana films. Food Res. Int. 40:365370, 2007.

[15] A. M. Langkilde, M. Champ and H. Anderson. Effect of high resistant starch banana flour (RS2) in vitro fermentation and small bowel excretion energy, nutrients and sterols: An ileostomy study. Amer. J. Clin. Nutr. 75:104-111, 2002.

[16] W. C. Lee, S. Yusof, N. S. A. Hamid and S. S. Baharinn. Optimizing conditions for hot water extraction of banana juice using response surface methodology (RSM). J. Food Engin. 75(4):473-479, 2006.

[17] M. M. Rahman, M. M. Rahman, U. F. Shahjadee, A. Z. Rupa and M. N. Hossain. Nutritional and microbiological quality of germinated soy flour. Bangladesh J. Sci. Ind. Res. 51(3); 167174, 2016.

[18] V. Jideani and F. Onwubali. Optimization of wheat sprouted soybean flour bread using response surface methodology. Afr. J. Biotech. 8(2):6364-6373, 2009.

[19] L. C. Okpala and P. N. Egwu. Utilization of broken rice and cocoyam flour blends in the production of cookies. Nig. Food J. 33(1):8-11, 2015.

[20] A. I. Adeyemi C. T. Akanbi and O. G. Fasora. Effect of soy fraction on some functional and rheological properties of maizebanana mixtures. J. Food Process. Preserv. 1:31-43, 1991. 
[21] L. G. Okpala, E. C. Okoli and E. A. Udensi. Physicochemical and sensory properties of cookies made from blends of germinated pigeon pea, fermented sorghum and cocoyam flours. Food Sci. Nutr. 1(1):8-14, 2013.

[22] S. Man, A. Paucean and S. Muste. Preparation and quality of gluten-free biscuit. Bull UASVM Food Sci. Technol. 71(1):39-41, 2014.

[23] E. I. Zoulias, S. Piknis and V. Oreopoulou. Effect of sugar replacement by polyol and acesulfame-k on properties of low fat cookies. J. Sci. Food Agric. 80:2049-2056, 2000.

[24] AOAC, Official Methods of Analysis (18 $8^{\text {th }}$ ed.). Association of Official Analytical Chemists. Washington D. C., USA, 2005.

[25] G. I. Onwuka. Food analysis and instrumentation. Naphthali Prints, Lagos, Nigeria. 2005, p. 89.

[26] D. R. Osborne and P. Voogt. The analysis of nutrients in foods. Academic Press, New York, 1978, 237.

[27] A. I. Ihekoronye and P. O. Ngoddy. Integrated Food Science and Technology for the Tropics. MacMillan Edu. Publishers, London, 1985, 172-193.

[28] A. M. S. Hussein, S. A. Amal, M. H. Amany, A. A. Abeer and H. R. Gamal. Physicochemical, sensory and nutritional properties of corn-fenugreek flour composite biscuits. Australian J. Basic Appl. Sci. 57:84-95, 2011.

[29] B. D. Igbabul, B. M. Iorliam and E. N. Umana. Physicochemical and sensory properties of cookies produced from composite of wheat, cocoyam and African yam bean. J. Food Res. 4(2):150-158, 2015.

[30] J. A. Ayo, V. A. Ayo, I. Nkama and R. Adewori. Physicochemical, in-vitro digestibility and organoleptic evaluation of "acha" - wheat biscuit supplemented with soybean flour. Nig. Food J. 25(1):77-89, 2007.

[31] A. I. Olagunju and B. O. Ifesan. Nutritional composition and acceptability of cookies made from wheat flour and germinated sesame (Sesamum indicum) flour blends. British J. Appl. Sci. Technol. 3(4):702-713, 2013.

[32] N. Dabel, B. D. Igbabul, A. Julius and B. Iorliam. Nutritional composition, physical and sensory properties of cookies from wheat, acha and mung bean composite flours. Int. J. Nutr. Food Sci. 5(6):401-406, 2016.

[33] C. S. Gaines. Influence of chemical and physical modifications of soft wheat protein on sugar-snap cookie dough consistency, cookie size and hardness. Cereal Chem. 67:73-77, 1990
[34] R. A. Miller, R. C. Hoseney and C. F. Morris. Effect of formula water content on the spread ratio of sugar-snap cookies. Cereal Chem. 74:669-671, 1997.

[35] J. Singh, N. Singh, T. R. Sharma and S. K. Saxena. Physicochemical, rheological and cookies making properties of corn and potato flour. Food Chem. 83:387-393, 2003.

[36] V. D. Banureka and T. Mahendran. Formulation of wheatsoybean biscuit and their quality characteristics. Trop. Agric. Res. Ext. 12(2):62-66, 2009.

[37] H. T. Abayomi, T. O. Oresanya, A. O. Opeifa and T. R. Rasheed. Quality evaluation of cookies produced from blends of sweet potato and fermented soybean flour. Inter. J. Nutr. Food Engin. 7(7):639-644, 2013.

[38] S. Kranz, M. Brauchla, J. L. Slavin and K. B. Miller. What do you know about dietary fibre intake in children and health? The effect of fibre intake on constipation, obesity and diabetes in children. Adv. Nutr. 3:47-53, 2012.

[39] M. D. Adrogue and N. E. Madias. Sodium and potassium in the pathogenesis of hypertension. New Engl. J. Med. 356:1966-1978, 2007.

[40] D. T. Liu, M. X. Wang, P. Kincaid-Smith and J. A. Whitworth. The effect of dietary potassium on vascular and glomerular lesions in hypertensive rats. Clin. Exp. Hyperten. 16:391-414, 1994.

[41] F. O. Abulude, L. O. Lawal, G. Ehikhamen, W. O. Adesanya and S. I. Ashafa. Chemical composition and functional properties of some prawns from the coastal area of Ondo State, Nigeria. Election. J. Environ. Agric. Food Chem. 5(1):1235-1240, 2006.

[42] M. B. Grosvernor and L. A. Smolin. Nutrition: From science to life. Harcourt College Publishers, New York. 2002, pp. 404469.

[43] G. S. Ranhotra, J. A. Gelroroth, S. O. Leinen, M. A. Vrnas and K. J. Lorenz. Nutritional profile of some edible plants from Mexico. J. Food Comp. Anal. 11:298-304, 1998.

[44] K. G. Dewey and K. H. Brown. Update on technical issues concerning intervention complementary feeding in young children in developing countries and implication for intervention programme. Food Nutr. Bull. 24:5-28, 2003.

[45] M. W. Short and J. E. Domagalski. Iron deficiency anemia: Evaluation and management. Amer. Fam. Physician. 87(2):98104, 2013. 